\title{
Organised Crime Typologies: Structure, Activities and Conditions
}

Vy Le*

Law and Justice Research Centre, School of Justice, Faculty of Law, Queensland University of Technology, GPO Box 2434, Brisbane QLD 4001, Australia

\begin{abstract}
Typologies are intended to assist researchers in understanding complex social phenomena. This paper reviews the current literature on organised crime typologies and argues that the majority of organised crime typologies are reflected to some extent in a typology developed by the United Nations Office on Drugs and Crime (UNODC) in 2002. Organised crime typologies can be categorised into three groups: models that focus on the physical structure and operation of an OCG, the activities of OCGs and the social, cultural and historical conditions that facilitate organised crime activity. This paper will only discuss models that examine the physical structure and operation of an OCG; the UNODC typology is exclusively focused on structural elements. Typologies on organised crime structure have developed largely in isolation from each other and appear disparate. This paper will analyse the formation of each typology to establish their individual elements. It will then identify which typologies and their respective characteristics can be aligned with or distinguished from the UN typology. The value of this review is that it will enable greater uniformity and consistency in academic discussion on organised crime typologies.
\end{abstract}

Keywords: Organised crime models, hierarchies, networks.

A key approach to disrupting and weakening organised crime activity is to develop a better understanding of the structure, operation and behaviour of organised crime groups (OCGs). Organised crime researchers have constructed typologies in an attempt to explain the structural and operational characteristics of OCGs. However, these typologies have developed largely in isolation from one another and generally, in response to organised crime activity occurring in a particular social and cultural milieu. This paper reviews the current literature on organised crime and argues that the majority of organised crime typologies are variations of the structures developed by the United Nations Office on Drugs and Crime (UNODC). This paper does not endeavour to engage in a discussion on the general purpose of typologies nor examine the merit of using typologies to explain criminal organisation. Rather, it attempts to coordinate discussion of the development of typologies in organised crime research.

This paper will firstly discuss the significance of studying organised crime structures and the types of models that have been developed to examine organised crime structure, activities and the social conditions which facilitate organised crime activity. The following section will discuss the UN typology and alternative organised crime models that have developed independently from the UN study. The alternative models include discussion on bureaucratic, patrimonial (patron-client) and network-based models.

*Address corresponding to this author at the Law and Justice Research Centre, School of Justice, Faculty of Law, Queensland University of Technology, GPO Box 2434, Brisbane QLD 4001, Australia; Tel: (07) 3138 4301, +617 3138 4306; E-mail: vykim.le@qut.edu.au
The final section examines an approach to developing a model of organised crime, with concluding remarks on the overall utility of the UN typology.

\section{WHY STUDY ORGANISED CRIME STRUCTURES?}

A key issue in conceptualising organised crime is the question of whether to focus on a group's organisation or a group's activities (Hagan 2006; Halstead 1994). The significance of structure is demonstrated in numerous studies which have documented the changing operational structure of OCGs from hierarchies to loose networks (Morselli 2009; Holmes 2009; Kenney 2007; Bruinsma and Bernasco 2004). Von Lampe (2012) argues that there is limited research which has provided any in-depth analyses of transnational criminal structures. Studying the structure of an OCG and developing models of their behaviour is one method of producing a body of knowledge that may assist law enforcement agencies in their investigative efforts to weaken and disrupt organised crime activity (Le and Lauchs 2012). Developing a comprehensive system of classification provides a useful tool for comparing the operational structures and activities of different OCGs (UNODC 2002).

\section{ORGANISED CRIME TYPOLOGIES: STRUCTURE, ACTIVITIES AND CONDITIONS}

The typologies produced by scholars in organised crime research may be categorised into three types: models that focus on the physical structure and operation of an OCG, models that focus on the activities of OCGs and models that focus on the social, cultural and historical conditions that facilitate 
organised crime activity. Similarly, Albanese (2011) proposed three types of organised crime models models focused on hierarchical structure, models that emphasise local, ethnic or cultural connections and economic models of organised crime. Hierarchical models and models emphasising local, ethnic or cultural connections are included in the discussion given the focus on operational structure. Some models incorporate more than one element for example, models that focus on structure and activity. Typologies that focus on the physical structure and operation of an OCG tend to discuss OCGs as operating under hierarchies, networks or a hybrid of the two forms. These typologies examine how the structure of an OCG is designed to facilitate their involvement in specific types of crime. A key approach to examining operational structure is finding points of "weakness" and vulnerability. Having the knowledge to identify these points in a criminal organisation may improve the policing capabilities of law enforcement agencies in disrupting organised crime activity. This paper will focus primarily on models that examine the physical structure and operation of an OCG because the UN typology is an example of a typology based purely on structure.

Models that emphasise the activities of OCGs are likely to be economic or enterprise models. Halstead (1998) distinguished two categories of models: groupfocused models and economic or activity-focused models. Group-focused models examine the structure and operation of an OCG whereas economic or activity-focused models focus on the profit-oriented activities of OCGs. Maltz (1976) created a typology based on a definition of organised crime that comprised of three key elements: means, political or economic objectives and manifestations of those objectives. This typology attempted to classify different forms of organised crime activity rather than distinguish between various types of OCGs. Therefore, this typology was not examined in any significant detail because of its focus on the activities and objectives of an OCG. Economic models describe organised crime as being governed by business and economic considerations; the activities of OCGs are defined by market dynamics, enterprise and the pursuit of profit (Albanese 2011; Williams and Godson 2002; Smith 1980). Williams and Godson (2002) argue that criminal organisations will behave and think according to rational business needs. They will consider factors such as new product opportunities, changes in the market, profit margins, competition and risk management (Williams and Godson 2002). This paper will exclude discussion on economic models because it focuses on the economic motivations underpinning an OCG's involvement in crime rather than the manner in which they are structured to commit crimes.

Models that focus on the social, cultural and historical conditions which facilitate organised crime activity examine factors such as ethnicity, political climate or market dynamics. Some OCGs recruit and operate on the basis of cultural, ethnic and kinship ties (Albanese 2011; Ianni 1972). The "ethnic" conception of organised crime in the literature tends to identify ethnicity with particular OCGs (e.g. Chinese triads, Japanese Yakuza or Italian mafia) or particular types of organised crime activities (e.g. Vietnamese gangs and drug trafficking) (Soudijn and Kleemans 2009). Some typologies were developed specifically to describe OCGs operating within a particular cultural and social context e.g. Chinese OCGs and triads, Sicilian mafia families. Ethnic-based OCGs are difficult to penetrate because shared language, culture and practices can defend and insulate groups from external attack (Williams and Godson 2002). Political models examine the ways in which OCGs exploit weak or corrupt state institutions or alternatively, find opportunities to forge relationships with legitimate political actors that will benefit the group's criminal activities (Williams and Godson 2002). This paper will not review political models because such models focus on conditions that facilitate organised crime activity.

Williams and Godson (2002) proposed two categories of models: models of conditions and models about how organized crime operates. Models of conditions include political, economic and social models whereas models of operation include strategic or risk management and composite or hybrid models. These models cover environmental factors and the individual attributes of criminal actors. For the purposes of this paper, only social models were examined from this typology because it identified the significance of culture, ethnicity and kinship in forming the basis for criminal organisation. Discussion on organised crime models generally fall under these categories. This paper will focus on the UN typology as the most comprehensive typology examining the physical structure and operation of OCGs. All other models will be discussed in light of the characteristics proposed in the UN typology.

\section{UNODC TYPOLOGY}

The Centre for International Crime Prevention (CICP) conducted a survey of forty organised crime 
groups across a number of jurisdictions (UNODC 2002). The data included ten main variables namely, structure, size, activities, trans-border operations, identity, violence, corruption, political influence and penetration into the legitimate economy. These variables were used to draw comparisons across different OCGs and to assist in developing typologies of organised crime (UNODC 2002). In 2002, the UNODC published a report entitled Results of a pilot survey of forty selected organized criminal groups in sixteen countries ("the Report") which established five models of organised crime. These models include standard hierarchy, regional hierarchy, clustered hierarchy, core group and criminal network (UNODC 2002). Academic discussion and application of the UN typology to organised crime activity is limited. Thus, the extent to which these models have been accepted by the international community remains uncertain.

To date, only three UNODC publications have applied the models to particular organised crime activities. However, these publications have only mentioned the UN models in passing or referred to the Report's objectives without applying the UN typology to OCGs (UNODC 2008; Shaw 2006; Antonopolous and Winterdyk 2006). A Home Office report (UK) reviewing the literature on upper level drug trafficking also mentions the Report and offers some critique of the Report's typology (Dorn, Levi and King 2005). The Home Office report suggests that the first two categories i.e. standard and regional hierarchy are relatively similar and are close to other organised crime models based upon bureaucratic or hierarchical structures. The criminal networks model can be applied broadly to other network-style OCGs whilst the clustered hierarchy appears to be the least supported by the Report's data (Dorn, Levi and King 2005). In order to assess the comprehensiveness of the UN typology, it is necessary to provide a brief description of each model.

\section{Standard Hierarchy}

The standard hierarchy is the "most common form" of an OCG (UNODC 2002: 34). The UNODC describe standard hierarchies as being characterized by a sole leader, a distinct chain of command and clearly defined roles. The 'top down' nature of the hierarchy facilitates strong internal control and discipline over its members through an implied or explicit code of conduct. Violence is predominantly used to maintain the internal and external order of the organisation. Standard hierarchies are generally mono-ethnic or comprised of members with similar personal backgrounds (UNODC 2002). An example of a standard hierarchy is the Liu Yong Syndicate in China. The syndicate is hierarchically structured (led by Liu Yong) and has a strong social identity given that its members were largely recruited from a particular region. The group members adhere to a strict code of conduct, which includes the use of violence and corruption when necessary. The syndicate were involved in trafficking in illicit goods and services, racketeering, gambling, prostitution and human smuggling (UNODC 2002).

\section{Regional Hierarchy}

Regional hierarchies have similar characteristics to standard hierarchies in so far as they have a chain of command, internal discipline, strong social or ethnic identity and distinct roles within the group (UNODC 2002). The primary difference between a regional and standard hierarchy is the decentralization of power; the process of allowing local organisations and group leaders to wield considerable independence and autonomy over a specific geographical region (UNODC 2002; Lyman and Potter 2007). A regional hierarchy allows OCGs to expand their membership and participate in numerous organised crime activities across a wide geographic spread, making it particularly advantageous for transnational criminal activity. The Hells Angels in Canada are a prime example of a regional hierarchy. The Hells Angels franchise their operations to Chapters governing particular locations. Each Chapter is led by a President who is the primary decision-maker and wields absolute control in that Chapter but reports strategically to a national President (UNODC 2002).

\section{Clustered Hierarchy}

A clustered hierarchy consists of smaller OCGs that operate under a central coordination body. Although clustered hierarchical OCGs maintain a degree of association, they are autonomous and independent in their activities and identity (UNODC 2002). The extent of their association relates to the coordination of criminal activities and enterprises. The UNODC recognises that clustered hierarchies are uncommon and are often the product of unique social environments such as those found in the prison system. For example, members of drug syndicates can still operate in prison by liaising with contacts outside of prison and between prisons. A clustered hierarchy allows for extensive membership and participation in multiple organised crime activities across a wide 
geographic area (UNODC 2002). An example of a clustered hierarchical structure is found within the "28s prison gang" in South Africa. The 28s developed tight knit criminal gangs by selecting particular inmates. The 28s competed with other prison gangs to monopolise informal trade and sexual services available in the prison system. Although members of the $28 \mathrm{~s}$ often joined other street gangs upon release, leadership of the 28s remained based in prison and therefore, there was a lack of cohesion amongst members (UNODC 2002).

\section{Core Group}

Core groups are an unstructured group of organised criminals surrounded by a larger network of associate members. The "core" of the group is relatively small (20 individuals or less) which makes it easier to maintain internal discipline (UNODC 2002). Core groups are characterised by a "flat" organisational structure, meaning power is shared amongst all members. It is difficult for law enforcement agencies to identify and track core groups because most core groups lack a strong social or ethnic identity and can operate behind the facade of a legitimate business being run by a small group of individuals (UNODC 2002; Lyman and Potter 2007). The Australian McLean syndicate exemplifies a core group. The recruitment of members was based on resources, skills and changing market forces. Therefore, members were recruited on an ad hoc basis which made membership of the syndicate both loose and adaptable (UNODC 2002).

\section{Criminal Network}

Criminal networks are highly adaptable and fluid networks comprised of individuals with various skills and characteristics, who are recruited for the purposes of particular jobs (UNODC 2002; Edwards and Gill 2002; Lyman and Potter 2007). The "pooling of resources", including individual skills, contacts and knowledge, is a significant advantage when undertaking trafficking activities within a criminal network (Morselli 2009). Members of networks organise themselves around an ongoing criminal enterprise and may not necessarily be connected by social or ethnic ties (Lyman and Potter 2007; UNODC 2002). The UNODC (2002) suggests that the maintenance of criminal networks is heavily dependent on personal ties and loyalties between participants and to the criminal enterprise. The dynamic nature of networks allows them to reform after the exit of key individuals. A number of modern drug trafficking syndicates resemble a criminal network. In the Netherlands, an Iranian formed a crime group (unnamed) who were engaged in people smuggling from Europe to Canada. The Iranian recruited a former client of his who established contacts and maintained the financial side of the operation (UNODC 2002). These two individuals then recruited additional members from their family and friends. The new members increased the group's client base and overall, the group forged alliances with contacts across Iran, Afghanistan and Canada (UNODC 2002).

The UN study is likely to be the most comprehensive study on the organisation and activities of OCGs. However, other structural models have emerged from studies that were conducted independently from the UN study. The following section will review alternative models of organised crime including bureaucratic models, patrimonial (patronclient) models, network-based models and typologies that incorporate both hierarchical and network models which are described as "hybrid" typologies.

\section{BUREAUCRATIC MODELS}

Cressey's (1969) bureaucratic model and Albanese' (2011) hierarchical model of organized crime are two models that have developed independently from the UN study. Both these models have characteristics which are reflected in the UN typology. Hierarchical models were the traditional representation of OCGs. Bureaucratic or hierarchical models generally characterise OCGs as operating under an extensive division of labour, with a supreme leader at the top of the hierarchy and different levels of subordinates, each with a defined role in the hierarchy (Roth 2010; Abadinsky 2007). Albanese (2011) describes this model of organised crime as being similar to a government structure; illegal activities are conducted with the approval of superiors and controlled by "higher-ups". Furthermore, bureaucratic groups are usually governed by a code of conduct which is strictly adhered to by the group's members (Roth 2010)

Roth (2010) stated that Cressey (1969) introduced the bureaucratic model in his study of Italian American criminal organisations, most notably, La Cosa Nostra. Cressey argued that OCGs closely resembled a "hierarchical bureaucracy". The bureaucratic model is a rationalized, hierarchical system which is impersonal and rigid in form (Abadinsky 2007). Criminal organisations like the Italian Mafia are "tightly structured in a hierarchical manner, resembling the 
bureaucracy found in the legitimate economy" (Pih, Hirose and Mao 2010). Various definitions of the bureaucratic model suggest that its characteristics include: a single leader, defined hierarchy, extensive division of labour, rigid and impersonal, various subordinates and code of conduct. Similar to Cressey's study of Italian American criminal organisations, the hierarchical model of organised crime emerged from Joseph Valachi's testimony of the existence of a nationwide, criminal organisation known as Cosa Nostra (Albanese 2011). Albanese (2011) described the hierarchical model as comprising of three main components:

a) "family" structure with ranks of authority from the boss down to the soldiers;

b) bosses oversee the activities of family members;

c) a "commission" of bosses handle inter-family relations and disputes.

The characteristics of the bureaucratic model are identical to a number of characteristics under the UN's standard hierarchy. These characteristics include having a leader, defined hierarchy, strong internal discipline and a social or ethnic identity. The social or ethnic identity is reflected in the emphasis on familybased criminal organisations e.g. Cressey's study of Italian-American criminal organisations. Similarly, Albanese' hierarchical model of organised crime focuses on the family structure which is consistent with the idea of having a strong social/ethnic identity in a standard hierarchy. The UN standard hierarchy also specifies the use of violence as being essential to the activities of hierarchical criminal organisations. A key characteristic of bureaucratic models is the code of conduct for members and therefore, it is likely that the use of violence is one method of enforcing appropriate conduct although this is not explicitly stated. Also, the bureaucratic model provides little guidance on whether OCGs operating under this structure are confined to specific territories. Thus, the element of "defined territory" in the standard hierarchy cannot be confirmed based on the characteristics of the bureaucratic model.

A number of scholars argue that whilst hierarchical models can be identified in criminal activity, the presence of these structures is unnecessary (Morselli 2009; Pearson and Hobbs 2001; Reuter and Haaga 1989). Although hierarchical organisations may have existed, they were not prerequisites for operational or financial success in organised crime activity (Reuter and Haaga 1989). The control of illegal markets is not dominated by a hierarchical, national crime group as previously suggested in the early organised crime literature (Reuter 1983). Therefore, hierarchical organisations are more likely to be "the exception rather than the rule" (Finckenauer 2005:65). Criminal associations are less hierarchical, less stable and considerably more "fluid" than the bureaucratic model suggests (Kleemans and van de Bunt 1999). Nonetheless, hierarchical models have survived because there are examples of OCGs, such as outlaw motorcycle gangs, that accurately reflect this organisational structure (Veno and van den Eynde 2008; Finckenauer 2005). Despite the emergence of criminal network forms, Williams (2001) suggests that hierarchical models are still significant because it is possible to have networks of hierarchies, hybrid organisational forms with some hierarchical components and a network dimension or even networks of networks. Thus, hierarchies and networks can co-exist in one criminal group.

\section{PATRIMONIAL (PATRON-CLIENT) MODELS}

Criminal organisations may restrict membership based on criteria such as ethnicity, kinship, race and criminal background (Finckenauer 2005). Abadinsky's (2007) patrimonial model is a network model that focuses on the relationships between families, friends and patrons. The patrimonial model assumed that OCGs are mono-ethnic due to its emphasis on recruiting members from family and friends (Halstead 1998). This model is characteristic of traditional societies which place strong emphasis on relationships of trust and emotional ties (Abadinsky 2007). An example of a patrimonial system is the Sicilian Mafia who have traditionally recruited new members from family, relatives and friends (Balsamo 2006). Thus, the basic unit of the Sicilian and American Cosa Nostra is the "family" (Paoli 2002). Similarly, Williams and Godson (2002) describe a "cultural model" of organised crime, one of three models developed under the broader category of "social models". Organised crime activity is facilitated by patron-client relationships, family and kinship ties and informal exchange networks. Kin-like relations are established through ritual processes that initiate members into a "brotherhood" (Paoli 2002). Loyalty and allegiance to the crime family is maintained through penalties for defections and therefore, violence is a mechanism used to enforce internal order (Williams and Godson 2002). Thus, key elements in the cultural model include family or kinship ties, informal exchange networks, territory and the use of violence when necessary. In 
developing a "local, ethnic model of organised crime", Albanese (2011) suggests that these groups are bound by cultural and ethnic ties, rather than a hierarchical structure. Furthermore, individuals controlled their own activities and recruited partners as they saw fit; they were unlikely to be members of a "national crime syndicate" (Albanese 2011:112).

Other studies have reinforced the significance of cultural and ethnic ties. Both Albini (1971) and lanni (1972) criticised Cressey's (1969) formal organisational model of La Cosa Nostra. Albini (1971) studied "syndicated crime" in the United States and argued that organised crime was not based on "rational hierarchies" but a fluid system of power relationships founded upon local and ethnic ties. Similarly, lanni (1972) studied an Italian-American organised crime family (Lupollo) and found that the Lupollo's organisation was based upon social networks, kinship ties and shared cultural values that were common in Southern Italian communities. Findings from these studies suggest little organisation amongst crime groups based on cultural or ethnic ties (Albanese 2011). However, a clear limitation of these studies is that they examined crime groups operating in a specific location and social context which cannot necessarily be generalised into a generic rule.

The patrimonial, cultural and local, ethnic models of organised crime appear to incorporate elements from both a standard hierarchy and a criminal network. Key characteristics across these models include fluidity in relationships, informal exchange networks and the importance of contacts, ties and loyalty as forming the basis for criminal organisation. These characteristics define the UN criminal networks model. However, some distinctions can be made between the models. The cultural model also describes characteristics such as territory and the use of violence. These characteristics are not identified in the UN criminal networks model but are part of the standard hierarchy model. Also, the UN criminal network model does not include a strong social/ethnic identity as a primary element but ethnicity and culture are key characteristics in the patrimonial, cultural and local, ethnic models. A strong social/ethnic identify is characteristic of standard and regional hierarchies. Therefore, the patrimonial, cultural and local, ethnic models appear to incorporate elements from both the standard hierarchy and criminal network models. Arguably, there is no requirement for a "hybrid" model combining hierarchies and networks because these two models can co-exist in one group.

\section{NETWORK MODELS}

There is a distinct trend in organised crime research away from studies on bureaucratic, hierarchical structures to loosely organised, flexible, criminal networks (von Lampe 2005). Previous research suggests that social relations form the basis of criminal networks and thus, OCGs operate in response to their social environment (Kleemans and van de Bunt 1999; Chambliss 1978; lanni 1972; Albini 1971). Some advantages of operating in networks include flexibility, rapid transfer of information, pooling of resources and skill sets and access to criminal opportunities. A network's adaptability and flexible nature enables them to be "lighter on their feet" than hierarchies (Powell 1990:30). Networks are dynamic entities and are more responsive to changes in their environment, given that the network's boundaries are far less defined than a hierarchy (Podolny and Page 1998). Flexibility is desirable in criminal networks because external pressure (e.g. law enforcement) or reduced levels of supply and demand in illicit markets may force OCGs to change established methods of operation.

Under the umbrella term of "social models", Williams and Godson (2002) identified three types of models: cultural model, ethnic network model and social network model. The cultural model has been previously discussed under patron-client models. The ethnic network model examines the effect of ethnic and diaspora networks in facilitating transnational organised crime activity (Williams and Godson 2002, 330). For example, the Chinese diaspora has brought Chinese immigrants to various parts of the Pacific, the United States and Europe. Diaspora communities can provide opportunities for recruitment, protection and support, especially if these communities are alienated from mainstream society. These networks are strengthened by shared language, culture and kinship ties (Williams and Godson 2002). The social network model encompasses both the cultural and ethnic network models. This model discusses networks as an "ideal vehicle" for executing transnational criminal activities. Networks are flexible, resistant to disruption, capable of expansion and able to respond quickly to market opportunities (Williams and Godson 2002:332). This model describes networks in relatively generic terms, particularly the advantages of operating under a network structure. The UN criminal networks model provides a broad definition of criminal networks and the generic characteristics provided in William and Godson's social network model can be aligned with the UN criminal networks model. 
Other scholars have developed more specific models based on network structures. Williams (2010) created a provisional network typology comprising of four types of networks: directed network, mesh network, transactional network and flux network. Although the basis of these structures is networks, Williams (2010) discusses variations in leadership, key players and organisation. A brief description of each network follows:

1) Directed network: formed and directed by a group of "core organisers" for a specific purpose (Williams 2010:69). The core of the network is the hierarchical component because it acts as a "steering mechanism" to direct and coordinate the network as a whole;

2) Mesh network: These networks are "decentralized and self-organising"; actors perform specific tasks and transact directly with other members without the need for a core body (Williams 2010:69). This type of network is best characterised by horizontal rather than vertical relationships between actors;

3) Transactional network: These networks rely heavily on brokers and middlemen who play critical roles at each stage of a "transaction". These networks are usually evident in drug trafficking groups. Directed network can be part of a transactional network;

4) Flux network: Flux networks are highly unstable, small and have little established structure as a result of its amorphous nature. There is limited trust between members and they appear to disband more easily compared to other network types. Groups operating in these networks usually cooperate for specific criminal activities or single projects.

The directed network reflects the characteristics of the UN core group. The key characteristic in both models is the "core group" of individuals, who direct the surrounding network members. The core group serves as the hierarchical component of the network. The mesh network appears to be a generic representation of the standard criminal network. The characteristics of this network are likely to be identified in any model of criminal networks. The transactional network is specific to certain types of organised crime activity which rely on the services of a broker or middleman. This type of network is unlike any of the UN models because it describes a network required for certain types of organised crime and at a particular stage in the commission of a crime. Transactional networks can coexist with directed networks and therefore, the presence of a transactional network may be identified with a core group. Criminals operating in flux networks appear largely opportunistic; they operate in an ad hoc and unstable manner. Given these characteristics, it is difficult to ascertain whether any OCGs would choose to operate under this model and if so, these groups are unlikely to satisfy the definition of organised crime.

Williams' (2010) typology of networks is largely covered by the UN typology. The directed network is reflected in the core group structure. The mesh network appears to be a relatively generic description of criminal networks and therefore, it does not provide evidence of any new characteristics in addition to the UN' criminal networks model. The transactional network is not covered in the UN typology but this network can exist in any OCGs that require the services of a broker e.g. drug trafficking groups. Arguably, transactional networks can be part of an OCG's structure but do not define a group's structure on its own. Flux networks are also not covered in the UN typology. However, OCGs are unlikely to be operating in flux networks because of its ad hoc, unstable nature.

\section{HYBRID TYPOLOGIES}

Hybrid typologies of organised crime incorporate both hierarchical and network models. The UN typology encompasses both hierarchical and network models because it attempts to cover a broader spectrum of organised crime structures. Similarly, Xia (2008) developed a typology of contemporary Chinese OCGs that incorporated both hierarchies and networks. From an alternative perspective, Lo (2010) suggests that traditional structure-control (hierarchical) or social network theories on Chinese OCGs cannot adequately reflect the state of modern, triad-organised crime in China and Hong. Lo does not propose another organised crime "model" but argues that the concept of "social capital" offers a more accurate explanation of the links between organised crime, social networks and political dynamics. Chinese legislators and law enforcement agencies have long perceived Chinese OCGs as operating within a traditional, hierarchical structure (Xia 2008). Xia (2008) suggests that in response to changing institutional and political environments, contemporary Chinese OCGs now operate in a range of organisational forms including 
hierarchies, 'hermit-crab' hybrid organisations and networks. Changes in the operational structure of Chinese OCGs may be attributed to the loss of central government control, tough anti-crime policies, absence of market regulations and the globalisation of crime and the market economy (Xia 2008).

\section{Hierarchies}

The hierarchical structure is typically characterised by a society name, a chief, rituals of induction and secret languages. Hierarchical groups often have a code of conduct or "handbooks" of rules and regulations which help to maintain the group's tightly organised structure. Hierarchical groups were created in three ways: 1) the influence of traditional secret societies, cults and banditry on current patterns of crime; 2) OCGs inspired by triad movies and television dramas and 3 ) the return of triads to mainland China as a result of China's "open door" policies and strong anticrime policing efforts in neighbouring countries (Xia 2008:13).

\section{"Hermit-Crab" Type Hybrids}

These criminal groups "take over the shells of legitimate hierarchies, such as business firms, nongovernmental organisation and state bureaucracies" (Xia 2008:14). The use of legitimate business fronts can facilitate money laundering and provides a safe haven for criminals to operate in a licit environment. After gaining control over some legitimate businesses, OCGs will often seek connections with political actors (Xia 2008). Thus, relationships between licit and illicit groups can provide beneficial opportunities for both parties.

\section{Criminal Networks}

Xia (2008) distinguishes between four different types of networks - multi-polar networks, cobwebs, production and distribution chains and a "hubs and spokes" structure. In multi-polar networks, numerous centres (or nodes) of criminals can co-exist (Xia 2008:17). Cobwebs are characterised by a leader occupying the centre of a network. Subordinate actors can interact amongst themselves but their interaction with the leader is more frequent and deferent (Xia 2008). Production and distribution networks operate in a "chain-like" structure by linking production, supply and demand lines, typically seen in drug and human trafficking operations (Xia 2008:19). In a "hub and spokes" structure, the network is controlled centrally by one criminal entrepreneur who coordinates illicit transactions with multiple actors. However, the central controller distances all actors, so that the actors have no knowledge about each other and therefore, no opportunity for horizontal communication (Xia 2008). Xia (2008) acknowledges that more Chinese OCGs are moving towards a network structure. Networks facilitate business expansion and its flexibility improves the OCG's ability to evade law enforcement.

Two of Xia's (2008) organisational types, hierarchies and criminal networks, are largely covered by the standard hierarchy and criminal network forms in the UN typology. Hermit crab hybrids are unlike any UN model; it describes the intersection between the licit and illicit worlds and how such relationships are beneficial to organised crime activity. Xia's version of criminal networks offers four different types of networks with some characteristics that can be distinguished from the UN criminal networks model. The UN criminal networks model suggests that individuals interact with each other in "horizontal" relationships, with no visible leader directing the network's actors. However, both Xia's "cobwebs" and "hubs and spokes" have a central figure that directs or oversees the network's activities. Also, Xia describes networks that are specific to certain types of organised crime activity. Production and distribution chains are common in trafficking crimes that require the planned movement of illicit goods. However, similar to Williams' (2010) transactional network, production and distribution chains can co-exist with other types of networks. Thus, production and distribution chains are more likely to be part of an OCG structure; it does not define an OCG's structure on its own.

\section{OTHER ORGANISED CRIME MODELS}

The characteristics of these models do not fall within hierarchical, network or hybrid models. These models aim to categorise OCGs using characteristics that are not exclusively focused on structure. Von Lampe (2002) proposes an "analytical model of organised crime", which appears to be a conceptual framework for developing a model than a model itself. Von Lampe (2002) suggests that any model of organised crime should include six key elements that cover both structural and environmental factors.

\section{Analytical Model of Organised Crime}

In proposing an alternative model of organised crime, von Lampe (2003:6) suggests that any "meaningful model" or organised crime must include six 
key elements - three elements that "define" or can be labelled as organised crime and three elements representing environmental factors. The three core elements in relation to labelling organised crime include: actors who cooperate in rational, planned criminal activities, structures that connect these actors and the criminal activities these actors are involved in. The three environmental elements include society, government and the realm of public discourse i.e. media von Lampe (2003:6). The model provides a "conceptual scheme" that accommodates for all social, cultural, economic or political factors and can be applied in any historical and geographical settings. The model addresses two key questions: 1) how patterns of criminal cooperation emerge and are transformed and 2) within those criminal structures, how positions of power develop that are relevant for the criminal structures themselves and for society at large. In the final step, the researcher must determine how the elements are connected and von Lampe (2003) provides an example of connecting elements based on a review of academic literature.

In essence, von Lampe (2003) proposes a "method" for developing a model of organised crime. The method prescribes that a comprehensive model of organised crime must encompass both the structural elements that define an OCG and the social context in which they operate. Von Lampe (2003:9) argues that it is the "diversity of manifestations of organised crime" under varying circumstances that provides valuable insight. The majority of organised crime models that focus exclusively on structural components provide limited scope for application in a variety of social and geographical settings. Von Lampe's approach aims to address that limitation by proposing a comprehensive "method" for developing a model of organised crime. Von Lampe's model varies significantly from the UN typology because it describes an approach to creating an analytical model of organised crime. One element of that approach is the inclusion of structures that connect the actors. This is likely to be drawn from the literature on theories of organised crime structures and therefore, could be inclusive of the UN typology.

\section{CONCLUSION}

A review of the literature on organised crime models has highlighted that models developed independently from the UN study appeared most consistent with that typology in terms of hierarchical models. The majority of bureaucratic-style models and hierarchies developed by other scholars produced very similar characteristics to the UN standard hierarchy. However, both the regional and clustered hierarchies were not identified in the review of models. Characteristics of the core group were identified in one model, being Williams' (2010) directed network. The most significant variation was evident in the analysis of criminal networks. The UN typology proposed a generic model of criminal networks with characteristics that are likely to be present in other criminal network models. However, network typologies developed by other scholars indicated the need to address additional factors such as social and cultural context or various types of organised crime activities which required specific forms of networks. Therefore, the UN criminal networks model appears inadequate on its own given the multiple variations of the network model produced in other studies.

The UN typology covered a broad spectrum of organised crime structures from hierarchies to networks. However, other typologies have demonstrated the significance of social and cultural context as having an impact on the operational structure of OCGs, particularly criminal networks which are more responsive to changes in the environment. Von Lampe's (2003) analytical model of organised crime attempts to encompass both structural and environmental factors to create a conceptual framework for developing organised crime models. Perhaps this is a more comprehensive approach to examining organised crime structures because the elements are not limited to a particular geographical setting. The existence of other hierarchical models (e.g. bureaucratic models) appears somewhat unnecessary given that the UN typology adequately covers these models and also proposes two additional types of hierarchies. Network models demonstrated more diversity in terms of detail and characteristics but the basis of these network models were still reflected in the UN criminal network model. Therefore, in terms of method and approach, the UN typology is the most comprehensive typology because at a fundamental level, it encompasses the majority of characteristics from other organised crime models.

\section{ACKNOWLEDGEMENTS}

I would like to thank Dr. Mark Lauchs for his advice and comments on earlier versions of the paper.

\section{REFERENCES}

Abadinsky, Howard. 2007. Organized crime. $8^{\text {th }}$ ed. London: Thomson Wadsworth. 
Albanese, Jay. 2011. Organized crime in our times. $6^{\text {th }}$ ed. Burlington, MA: Anderson Publishing.

Albini, Joseph L. 1971. The America Mafia: Genesis of a Legend. New York: Appleton-Century-Crofts.

Antonopolous, Georgios and John Winterdyk. 2006. "The Smuggling of Migrants in Greece: An Examination of its Social Organization." European Journal of Criminology 3(4): 439461.

http://dx.doi.org/10.1177/1477370806067912

Balsamo, Antonio. 2006. "Organised crime today: The evolution of the Sicilian Mafia." Journal of Money Laundering Control 9(4): 373-378.

http://dx.doi.org/10.1108/13685200610707626

Bruinsma, Gerben. and Wim Bernasco. 2004. "Criminal groups and transnational illegal markets." Crime, Law and Social Change 41: 79-94. http://dx.doi.org/10.1023/B:CRIS.0000015283.13923.aa

Chambliss, Williams. 1978. On the take: From petty crooks to Presidents. Bloomington: Indiana University Press.

Cressey, Donald R. 1969. Theft of the nation: the structure and operations of organized crime in America. New York: Harper \& Row.

Dorn, Nicholas., Michael Levi and Leslie King. 2005. Literature review on upper level drug trafficking. London: Home Office.

Edwards, Adam. and Peter Gill. 2002. "Crime as enterprise? The case of "transnational organised crime"." Crime, Law and Social Change 37: 202-223 http://dx.doi.org/10.1023/A:1015025509582

Finckenauer, James O. 2005. "Problems of Definition: What is Organized Crime?" Trends in Organized Crime 8(3): 63-83. http://dx.doi.org/10.1007/s12117-005-1038-4

Hagan, Frank E. 2006. 'Organized crime' and 'organized crime': Indeterminate Problems of Definition" Trends in Organized Crime 9(4): 127-137.

http://dx.doi.org/10.1007/s12117-006-1017-4

Halstead, Boronia. 1998. "The Use of Models in the Analysis of Organized Crime and Development of Policy." Transnational Organized Crime 4(1): 1-24.

Holmes, Leslie. 2009. "Crime, organised crime and corruption in post-communist Europe and the CIS." Communist and PostCommunist Studies 42: 265-287. http://dx.doi.org/10.1016/j.postcomstud.2009.04.002

Ianni, Francis.A.J. 1972. A Family Business: Kinship and Social Control in Organized Crime. New York: Russell Sage Foundation.

Kenney, Michael. 2007. "The Architecture of Drug Trafficking: Network Forms of Organisation in the Colombian Cocaine Trade." Global Crime 8(3): 233-259. http://dx.doi.org/10.1080/17440570701507794

Kleemans, Edward R and Henk van de Bunt. 1999. "The Social Embeddedness of Organized Crime." Transnational Organized Crime 5(1): 19-36.

Le, Vy K. and Mark Lauchs. 2012. "Models of South-East Asian Organised Crime Drug Operations in Queensland." Asian Criminology.

http://dx.doi.org/10.1007/s11417-011-9124-9

Lo, T Wing. 2010. "Beyond Social Capital: Triad Organized Crime in Hong Kong and China." British Journal of Criminology 50: 851-872.

http://dx.doi.org/10.1093/bjc/azq022

Lyman, Michael. and Gary Potter. 2007. Organized crime. $4^{\text {th }}$ ed. New Jersey: Pearson.

Maltz, Michael D. 1976. "On Defining Organized Crime: The Development of a Definition and Typology." Crime and Delinquency 22: 338-346.

http://dx.doi.org/10.1177/001112877602200306
Morselli, Carlo. 2009. Inside Criminal Networks. Montreal: Springer. http://dx.doi.org/10.1007/978-0-387-09526-4

Paoli, Letizia. 2002. "The paradoxes of organized crime." Crime, Law and Social Change 37: 51-97. http://dx.doi.org/10.1023/A:1013355122531

Pearson, Geoffrey. and Dick Hobbs. 2001. Middle market drug distribution. London: Home Office Research, Development and Statistics Directorate.

Pih, Kay Kei-Ho., Akihiki Hirose and KuoRay Mao. 2010. "Gangs as contractors: the social organization of American Taiwanese youth gangs in Southern California." Trends in Organized Crime 13: 115-133. http://dx.doi.org/10.1007/s12117-010-9095-8

Podolny, Joel M., and Karen L. Page. 1998. "Networks Forms of Organization." Annual Review of Sociology 24: 57-76. http://dx.doi.org/10.1146/annurev.soc.24.1.57

Powell, Walter W. 1990. "Neither Market nor Hierarchy: Network Forms of Organization." Research in Organizational Behaviour 12: 295-336.

Reuter, Peter. 1983. Disorganized Crime: The Economics of the Invisible Hand. Cambridge: MIT Press.

Reuter, Peter. and John Haaga. 1989. The Organization of HighLevel Drug Markets: An exploratory study. Santa Monica: RAND.

Roth, Mitchel P. 2010. Organized crime. New Jersey: Prentice Hall.

Shaw, Mark. 2006. "Drug trafficking and the development of organized crime in post-Taliban Afghanistan." Pp. 189-214 in Afghanistan's Drug Industry: Structure, Functioning, Dynamic, and Implications for counter Narcotics Policy, edited by D. Buddenberg and W.A. Byrd. Kabul: United Nations Office on Drugs and Crime.

Smith, Dwight. C. 1980. "Paragons, Pariahs and Pirates: A Spectrum-Based Theory of Enterprise." Crime and Delinquency 26: 358-386.

http://dx.doi.org/10.1177/001112878002600306

Soudijn, Melvin R.J. and Edward R. Kleemans. 2009. "Chinese organized crime and situational context: comparing human smuggling and synthetic drugs trafficking." Crime, Law and Social Change 52: 457-474

http://dx.doi.org/10.1007/s10611-009-9203-3

United Nations Office on Drugs and Crime. 2008. 027 Workshop: Transnational Organized Crime - Impact from Source to Destination - Background Paper: Proceedings of the Vienna Forum to fight Human Trafficking, Vienna Austria, February 2008. Vienna: Austria Center.

United Nations Office on Drugs and Crime. 2002. Results of a pilot survey of forty selected organized criminal groups in sixteen countries. Vienna: United Nations Office on Drugs and Crime.

Veno, Arthur and Julie van den Eynde. 2008. Submission 10: Parliamentary Joint Committee on the Australian Crime Commission Inquiry into the legislative arrangements to outlaw serious and organised crime groups. Canberra.

von Lampe, Klaus. 2012. "Transnational organized crime challenges." Crime, Law and Social Change 58(2): 179-194. http://dx.doi.org/10.1007/s10611-012-9377-y

von Lampe, Klaus. 2005. Beg, Steal of Borrow: The Study of Organized Crime and the Infusion of Concepts and Theories from Other Disciplines: Annual Meeting of the American Society of Criminology (ASC), Toronto Canada, November 2005. Marburg: Free University Berlin.

von Lampe, Klaus. 2004. "Making the second step before the first: Assessing organized crime." Crime, Law and Social Change 42(4): 227-259. http://dx.doi.org/10.1007/s10611-005-5305-8

von Lampe, Klaus. 2003. The Use of Models in the Study of Organized Crime: Proceedings of the 2003 Conference of the European Consortium for Political Research (ECPR), 
Marburg Germany, September 2003. Marburg: Freie Universitat Berlin.

Williams, Phil. 2010. "Tailoring Strategies Against Criminal Networks." Paper presented at the $2^{\text {nd }}$ Annual Illicit Networks Workshop, Wollongong, December 6-7. http: //ctcp.uow.edu.au/content/groups/public/@web/@law/@ctcp/ documents/doc/uow093824.pdf

Williams, Phil. 2001. "Transnational Criminal Networks." Pp 61-97 in Networks and Netwars: The Future of Terror, Crime and Militancy, edited by John Arquilla and David Ronfeldt. California: RAND.
Williams, Phil. and Roy Godson. 2002. "Anticipating organized and transnational crime." Crime, Law and Social Change 37(4): 311-355. http://dx.doi.org/10.1023/A:1016095317864

Xia, Ming. 2008. "Organizational Formations of Organized Crime in China: perspectives from the state, markets, and networks." Journal of Contemporary China 17(54): 1-23. http://dx.doi.org/10.1080/10670560701693039

Received on 07-09-2012

Accepted on 15-10-2012

Published on 05-11-2012

DOI: http://dx.doi.org/10.6000/1929-4409.2012.01.12

(C) 2012 Vy Le; Licensee Lifescience Global.

This is an open access article licensed under the terms of the Creative Commons Attribution Non-Commercial License (http://creativecommons.org/licenses/by-nc/3.0/) which permits unrestricted, non-commercial use, distribution and reproduction in any medium, provided the work is properly cited. 